\title{
Blood serum level of TSH and thyroid hormones and thyroid tissue content of iodine in rats under restricted selenium and iodine supply
}

\author{
E. Glattre ${ }^{1}$, V. Eybl ${ }^{2}$, D. Kotyzova ${ }^{2}$, M. Mihajlevic ${ }^{3}$, R. Pikner ${ }^{2}$ and O. Topolcan ${ }^{2}$ \\ ${ }^{I}$ Cancer Registry of Norway, Norway \\ ${ }^{2}$ Charles University in Prague, Faculty of Medicine in Pilsen \\ ${ }^{3}$ Charles University in Prague, Faculty of Science, Czech Republic
}

\begin{abstract}
NORSK SAMMENDRAG
128 Wistar hunrotter, 30 dager gamle, ble foret med spesialkost i fire uker pluss en forsøksperiode på maksimalt 36 timer. Blant dyrene ble 114 forsøksdyr og 7 kontroller satt på fôr med lavt innhold av selen og jod mens 7 kontrolldyr fortsatt ble holdt på standardfôr. Etter fire uker ble seks grupper forsøksdyr gitt KI i.p. i doser fra 5 til $1000 \mu \mathrm{g}$ I. En tredel av dyrene fra alle eksponeringsgrupper ble avlivet 18 timer etter injeksjonen, en tredel fra alle eksponeringsgrupper ble avlivet 24 timer etter injeksjonen og siste tredel ble avlivet 36 timer etter. Total T4, T3, rT3 og TSH ble bestemt i serum mens jodnivået ble bestemt som våtvektskonsentrasjonen i skjoldkjertelvevet. Ni rotter gikk tapt før forsøket kunne avsluttes. Klarest for rotter avlivet 18 timer etter jodinjeksjonen kan man se at kurven for TSH er bimodal. Man fant at jodmengder helt ned til 5-10 $\mu \mathrm{g} /$ rotte ga signifikant forhøyet TSH-nivå. Dette tilsvarer mengder som mennesker lett får i seg på daglig basis på en kost rik på sjømat. Resultatet av eksperimentet blir diskutert med bakgrunn i E.D.Williams’ 25 år gamle tese om at jod i overskudd i kosten medvirker til øket risiko for utvikling av papillært karsinom i skjoldkjertelen.
\end{abstract}

In 1977 E.D.Williams et al. suggested that high intakes of iodine most likely were involved in the carcinogenesis of thyroid papillary carcinoma (1). There exist several good arguments in favour of this hypothesis. Here it may be sufficient to mention the AustrianSwiss experience with increasing thyroid papillary carcinoma occurence in the years after the upstart of the goiter prevention programme with iodination of salt $(2,3)$ in these countries. Another argument is the conspicuous geographic distribution of a high incidence of thyroid cancer along oceanic coasts. This is an iodinerich zone in which papillary carcinoma occurs more frequently than follicular carcinoma. On the other hand, the latter occurs relatively more frequently in iodine-deficient areas of the world $(4,5)$.

In a paper from 1992 Kanno et al. presented a smoothed neoplasia incidence curve showing an ushaped relationship between percentage of thyroid neoplastic lesions and iodine intake $(\mu \mathrm{g}$ per rat per day) in rats pretreated with N-bis(2-hydroxypropyl)nitrosamine (DHPN) (6). The iodine intake range, varying from 0.1 to $3,000 \mu \mathrm{g} / \mathrm{rat} /$ day on the $\mathrm{x}$-axis, had been divided by the authors into two overlapping intervals, one iodine deficiency interval from 0.1 to 9.7 $\mu \mathrm{g} / \mathrm{rat} /$ day and one iodine excess interval from 2.6 $\mu \mathrm{g} / \mathrm{rat} / \mathrm{day}$ and upwards. The curve first declines steeply from left to right and then levels off. For intakes of $1-2 \mu \mathrm{g} / \mathrm{rat} /$ day the curve appears to attain its minimum.
It tends to increase slightly in the remaining part of the deficiency interval. In the excess interval the curve increases further with increasing values of daily intake.

In the 1990's E.D.Williams summarized the general scientific experience with experimental thyroid cancer research. He coined the doctrine that the interaction between mutagenic and goitrogenic factors represents the usual mechanism underlying causation of malignancies of the thyroid gland (7). The important thing with this doctrine is that it defines the combined action of two chemical substances as a basic mechanism underpinning spontaneously-occurring, differentiated thyroid carcinoma.

In the mid-1980's we succeeded in showing that the thyroid gland was the most selenium-rich tissue in the human body and, also, that higher levels of serum selenium seemed to protect against the development of thyroid cancer $(8,9)$. In a recent study on mice, hitherto unpublished, we observed that the body seemed to mobilize selenium and reallocate it to the thyroid gland when exposed to high doses of halogen $(\mathrm{I}, \mathrm{Br})$.

This is the background information on which we decided to carry out animal experiments to see if even smaller doses of iodine could provoke a release of TSH. Since selenium apparently protects the thyroid gland, we decided to keep the animals on a low daily supply of selenium (Se) and of iodine (I) for four weeks prior to the experiment. 


\section{MATERIAL AND METHODS}

\section{Material and design}

The experiment was divided into a preparatory phase lasting from 31.10 .00 to 28.11 .00 during which 128 Wistar female rats were fed special feeds. This phase was succeeded by a test phase of 36 hours' duration. The 128 rats were 30 days old and weighed on average $103 \mathrm{~g}$ at the beginning of the preparatory phase. Seven control rats fed Altromin $\mathrm{C} 1000$, the standard diet, weighed $209 \mathrm{~g}$ on average at the end of the study. Seven controls and 114 study animals were fed Altromin $\mathrm{C} 1042$, low in both Se and I. They weighed ca. $205 \mathrm{~g}$ at the end of the study. All animals were caged under equal $12 \mathrm{~h}$ day and $12 \mathrm{~h}$ night conditions. The $\mathrm{C} 1000$ feed contained, according to producer, $0.46 \mathrm{mg}$ iodine and $0.273 \mathrm{mg}$ selenium per $\mathrm{kg}$ while $\mathrm{C} 1042$ contained $0.010 \mathrm{mg} \mathrm{I}$ and $0.045 \mathrm{mg}$ Se per $\mathrm{kg}$. Feed and water were available ad libitum.

At the beginning of the test phase $3 \times 5$ rats got $5 \mu \mathrm{g}$, $3 \times 7$ got $10 \mu \mathrm{g}, 3 \times 7$ got $50 \mu \mathrm{g}, 3 \times 7$ got $100 \mu \mathrm{g}, 3 \times 7$ got $500 \mu \mathrm{g}$ and $3 \times 5$ got $1000 \mu \mathrm{g}$ of iodine (as KI) injected i.p. Of these animals $1 / 3$ in each exposure group, minus one lost to follow-up, i.e. altogether 37 animals, were sacrificed 18 hours after injection. Similarly $1 / 3$ in each exposure group, minus four lost to follow-up, altogether 34, were sacrificed 24 hours after injection and the last $1 / 3$ from each group minus two lost, altogether 36, were sacrificed 36 hours after injection. They were all sacrificed in anesthesia. Blood and thyroid tissue samples were taken postmortem from both test and control animals for further examination.

\section{Methods}

For the radioimmunoassay of total $\mathrm{T} 3$ and total $\mathrm{T} 4$ kits from Immunotech, Czech Republic were used, and for the radioimmunoassay of reverse $\mathrm{T} 3$ and rat $\mathrm{TSH}$, kits from BIOCODE, Belgium.

Iodine analysis was performed by ICP-MS spectrometry (VG Elemental) expressing the iodine contents in micrograms per gram of wet tissue weight $[\mu \mathrm{g} / \mathrm{g}$ wtw].

Statistical analysis: Student's t-tests (10).

\section{RESULTS}

The concentrations of the thyroid hormones T4, T3, rT3 and TSH in plasma and of iodine in thyroid tissue of the control animals are presented in Table 1. Both for animals living on standard feed (Altromin C1000) and animals living on special feed (Altromin C1042) the tabulated figures represent the values determined at the start of the preparatory phase and at the end of the test phase.

An important observation is the increase in TSH following injections of even smaller doses of iodine. Figure 1 shows that the TSH concentration vs. iodine dose forms a bimodal curve 18 hours after injection. There is first a moderate, but significant $(\mathrm{p}<0.01)$, increase of TSH for doses 5-10 $\mu \mathrm{g}$ I per rat as compared to controls on standard feed. For increasing I doses, TSH seems to level off, but for doses of $100 \mu \mathrm{g} \mathrm{I} \mathrm{per}$ rat, TSH starts a steep increase, reaching its highest value at $1000 \mu \mathrm{g}$ I per rat. Twenty-four hours after injection the TSH concentration tends to be lower for most iodine doses and this tendency is quite obvious for all dose levels 36 hours after injection. The bimodal form of the TSH curve 18 hours after injection remains recognizable even 24 and 36 hours after.

Eighteen hours after injection the concentrations of $\mathrm{T} 4$ and T3 first tend to decrease and then increase, finally to decrease again for the very high doses of iodine. Twenty-four and 36 hours after injection both the T4 and T3 tend to increase in the lower part of the iodine exposure range, reaching a peak in the intermediate part. $\mathrm{T} 4$ and $\mathrm{T} 3$ then decrease with increasingly higher iodine doses. The T3 curve, 36 hours after injection, is inversely u-shaped. On the other hand, the rT3 curve, determined 18 hours after iodine injection, is approximately straight with a negative slope. The 24- and 36-hour curves are highly irregular and not shown in fig. 1.

The 18-hour curve for the thyroid tissue I concentration is u-shaped. In the medium exposure range the tissue concentration clearly increases during the last $36-18=18$ hour period of the test phase.

\section{DISCUSSION}

The study has shown that female Wistar rats living on a feed low in Se and I for four weeks develop a significantly greater plasma concentration of TSH than do control animals when injected i.p. with I, and that this response lasts for many hours. This is the case with doses of I as low as 5-10 $\mu \mathrm{g}$ per rat. It is absolutely possible, at least for people who selectively enjoy seafood, to consume on a daily basis iodine in proportionate amounts.

Table 1. Concentration of iodine (I) in thyroid gland and of thyroid hormones T4, T3, rT3 and TSH in serum of control animals at the end of study by type of feed $( \pm S D)$.

\begin{tabular}{|c|c|c|c|c|c|}
\hline Diet & $\mathrm{I}(\mathrm{mg} / \mathrm{g})$ & $\mathrm{T} 4(\mathrm{nmol} / \mathrm{l})$ & $\mathrm{T} 3(\mathrm{nmol} / \mathrm{l})$ & rT3 (ng/dl) & $\mathrm{TSH}(\mathrm{ng} / \mathrm{ml})$ \\
\hline Standard diet (Altromin C1000) & $0.65 \pm 0.12$ & $57.0 \pm 9.2$ & $0.92 \pm 0.22$ & $11.3 \pm 3.5$ & $2.10 \pm 0.70$ \\
\hline Diet low in I and Se (Altromin C1042) & $0.62 \pm 0.20$ & $54.0 \pm 10.2$ & $0.90 \pm 0.26$ & $16.6 \pm 5.8$ & $4.20 \pm 1.20$ \\
\hline
\end{tabular}


Figure 1. Thyroid hormone T4 (nmol/l), T3 (nmol/l), rT3 (ng/dl), TSH (ng/ml) and thyroid tissue concentration of iodine $(\mu \mathrm{g} / \mathrm{g}$ w.w.) in Wistar female test rats vs. amount of iodine injected i.p. and time from injection to death. Prior to injection all animals lived for four weeks on a feed low in Se and I. The curve $\bullet-\bullet$ signifies that the animals lived 18 hours after injection, $\bullet----\bullet$ signifies that they lived 24 hours and $\bullet . \cdots \cdots \cdots \cdot \cdots \cdot$ that they lived 36 hours after injection. Control values are indicated by arrows; * means that these control rats lived on Altromin C1042 low in selenium and iodine.

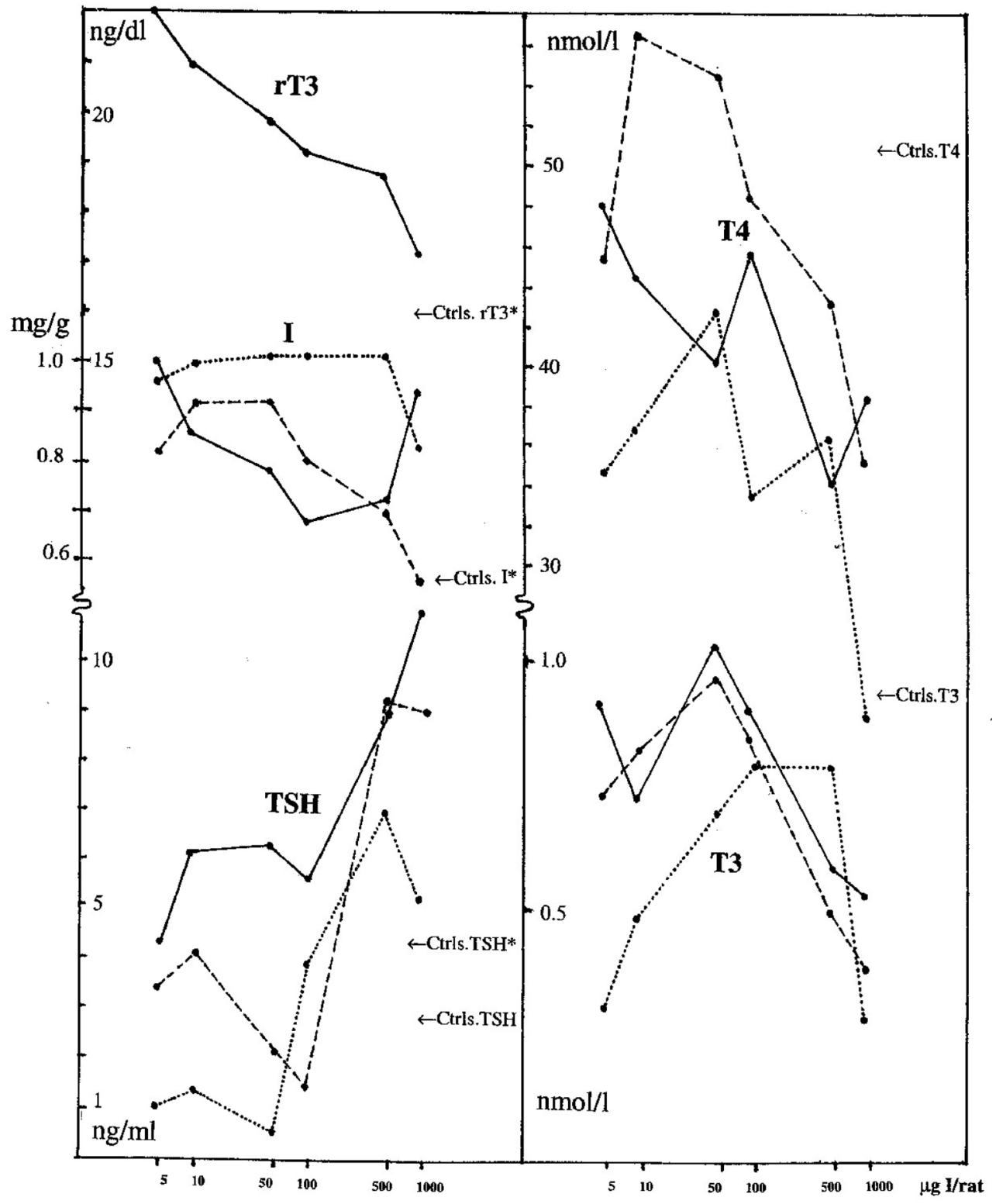

We prefer to interpret the significantly elevated TSH of control rats living on Altromin C1042 compared to control rats living on Altromin C1000 (Fig. 1) as a probable sign of stress on thyroid cells caused by restrictions in the supply of I and Se, both elements being of the utmost importance for the thyroid. Selenium is a cofactor in important extranuclear and intranuclear thyroid enzymes. Selenium containing glutathione peroxidase (GPX) protects tissues against oxidative stress and damage caused by mutagens, while thioredoxin reductase (TrxR) is crucial for repair and replication of DNA. Essential dehalogenases are also dependent on Se for their optimal function $(11,12)$.
Thyroid cells respond to a lot of growthstimulating substances, which work by activating one of three signal transduction pathways leading from the cell surface to the nucleus. These reaction routes are the TSH pathway, the thyrosine kinase pathway and the receptor/phospholipase $\mathrm{C}$ pathway. The latter two initiate mitosis, but not cell differentiation. We consequently regard it less likely that these two signal pathways are frequently involved in the development of the differentiated types of thyroid cancer i.e. of papillary and follicular carcinoma. The TSH pathway, on the other hand, brings about both proliferation and cell differentiation (13). 
A closer look at Kanno et al.'s point plot underlying their smoothed incidence curve (v.s.) reveals that the point plot is bimodal within their I excess interval on the $\mathrm{x}$-axis: The point plot indicates a small increase in incidence from 1 to $10 \mu \mathrm{g} \mathrm{I} / \mathrm{rat} /$ day, then it levels off and runs parallel to the axis for I exposure from 10 to $100 \mu \mathrm{g} \mathrm{I} / \mathrm{rat} /$ day and finally for exposures above 100 $\mu \mathrm{g} \mathrm{I} / \mathrm{rat} /$ day the point plot indicates a sharp increase with increasing amounts of I. Hence there is a clear similarity between Kanno et al.'s basic results concerning incidence of rodent thyroid cancer by excessive intake of I and the TSH curve presented in Figure 1. It is therefore tempting to hypothesize that TSH, under proper conditions, might be the proliferation-inducing substance in the carcinogenesis of differentiated thyroid carcinoma. If so, this is nothing but a more specified version of D.E.Williams' hypothesis.

The bimodality of the TSH curve, most conspi- cuously shown at 18 hours after injection (Figure 1), is possibly a consequence of the Wolff-Chaikoff effect (14), because both I and T4, 18 hours after injection, demonstrate a downward trend between 5 and $100 \mu \mathrm{g}$ I. In addition, there is a decrease in rT3 (15). Based on the aforementioned similarity between the TSH-curve in Figure 1 and the point plot by Kanno et al. for thyroid neoplasms by excessive I exposure, it is not unlikely that the Wolff-Chaikoff effect exerts a cancerpreventive influence.

In conclusion - on the basis of our results, not incompatible with existing knowledge - we wish to reactivate the hypothesis, launched some 25 years ago by E.D.Williams, that the physiologic reactions to iodine exposure represent an important mechanism involved in one of the carcinogenetic pathways leading to cell transformation and the emergence of papillary carcinoma of the thyroid.

\section{REFERENCES}

1. Williams ED, Doniach I, Bjarnason O, Michie W. Thyroid cancer in an iodide rich area. Cancer 1977; 39: 215-22.

2. Thalmann A. Die Haufigkeit der Struma maligna am Berner Pathologischen Institut von 1910-1950 und ihre Beziehung zur Jodprophylaxe des endemischen Kropfes. Schweiz Med Wochenschr 1984; 84: 473-8.

3. Hofstadter F. Frequency and morphology of malignant tumours of the thyroid before and after the introduction of iodine prophylaxis. Virchows Arch A 1980; 385: 263-70.

4. Glattre E, Thoresen SO, Johansen A. Incidence of thyroid cancer in Norway 1970-79. Geographical distribution of histologic types. In: Proceedings of the $1^{\text {st }}$ international symposium on geochemistry and health. Science Reviews, London, 1985: 96-106.

5. Figge J. Epidemiology of thyroid cancer. In: Thyroid Cancer, Wartofsky L, ed. Totawa, New Jersey, 2000: 77-83.

6. Kanno J, Onodera H, Furuta K, Maekawa A, Kasuga T, Hayashi Y. Tumor-promoting effects of both iodine deficiency and iodine excess in the rat thyroid. Toxicol Pathol 1992; 20: 226-35.

7. Williams ED. Thyroid tumorigenesis. Horm Res 1994; 42: 31-4.

8. Glattre E, Thomassen Y, Thoresen SO, Haldorsen T, Lund-Larsen PG, Theodorsen L, Aaseth J. Prediagnostic serum selenium in a case-control study of thyroid cancer. Int J Epidemiol 1989; 18: 45-9.

9. Aaseth J, Frey H, Glattre E, Nordheim G, Ringstad J, Thomassen Y. Selenium concentration in the human thyroid gland. Biol Trace Elem Research 1990; 24: 147-52.

10. Altman DG. Practical statistics for medical research. London, 1991: 191-8.

11. Allan CB, Lacourciere GM, Stadtman TC. Responsiveness of selenoproteins to dietary selenium. Annu Rev Nutr 1999; 19: 1-16.

12. Berry MJ, Banu L, Larsen PR. Type I iodothyronine deiodinase is a selenocysteine-containing enzyme. Nature 1991; 349: 438-40.

13. Figge J. Molecular pathogenesis of thyroid cancer. In: Thyroid Cancer, Wartofsky L, ed. Totawa, New Jersey, 2000: 57-75.

14. DeGroot LJ, Larsen PR, Refetoff S, Stanbury JB. The thyroid and its diseases, $5^{\text {th }}$ edn. New York, 1984: 13641.

15. Capen CC, Delellis RA, Williams ED. Thyroid carcinogenesis and xenobiotic chemicals. In: Radiation and thyroid cancer, Thomas G, Karaoglou A, Williams ED, eds. London, 1999: 172-5. 